\title{
Corporate Practices of Green Human Resources Management
}

\author{
Ardeshir Bazrkar \\ Researcher and Lecturer, ardeshir.bazrkar@gmail.com
}

Ali Moshiripour

Post-Graduate Student, moshiripourali@gmail.com

Department of Industrial Management, North Tehran Branch, Islamic Azad University, 9, Pasdaran Ave., Tehran, Iran

\begin{abstract}
G reen education and development has a great impact upon improving the environmental performance of companies. Using the example of Iranian small and medium-sized oil and gas enterprises, this article evaluates the practices' effect on environmental performance. The survey covered 386 employees from 30 companies. The most common measures of green human resources management were analyzed. All these practices have a positive and significant effect on the environmental performance

of companies. The action of green education and development was introduced as the most effective measure. The results also demonstrated that four practices of green human resources management have a positive and significant impact upon performance due to environmental knowledge. Companies can use the findings of this research when implementing the green human resources management practices and continuous improvement initiatives for the environmental performance
\end{abstract}

Keywords: green skills; green human resources management practices; environmental performance; small and medium-sized enterprises; environmental knowledge of employees; oil and gas industry
Citation: Bazrkar A., Moshiripour A. (2021) Corporate Practices of Green Human Resources Management. Foresight and STI Governance, 15(1), 97-105. DOI: 10.17323/25002597.2021.1.97.105 
$\mathrm{U}$ ndoubtedly, the corporate world is the major beneficiary in the discussion on environmental issues, and thereby, it is seen as an important part of the solution to resolve environmental hazards. Over the last several decades, a general consensus has raised the need for their active engagement in environmental management [González, González, 2006]. Several units of an organization, including marketing, information technology, and finance, need to work together to implement any corporate environmental program to make a positive and common impact, among which, the human resources management unit is recognized as a highly important factor [Pham et al., 2019; Clair, Milliman, 2017; Jaramillo et al., 2018]. There is clear evidence, based on which, a large portion of the workforce in the business world have strong feelings about the environment, since in today's era, employees show more commitment to and greater satisfaction with organizations that actively participate in accepting and approving green activities.

Researchers confirm that green human resources management practices and measures have a significant impact upon the environmental performance of the organization by reducing waste and increasing organizational productivity [Jabbour, 2013; Pham et al., 2019]. Previous studies suggest that environmental knowledge affects the employees' green behavior and their participation in environmental activities [Angelovska et al., 2012; Pan et al., 2018; Guzman et al., 2020]. It is one of the important components that shapes people's attitudes toward environmentally friendly behaviors [Zhao et al., 2014].

The development of green practices is of particular importance for Iran, which, like many other countries, encountered many problems over the course of recent decades, including those related to industrial pollutants. The severity of environmental pollution from waste in cities and concentration of industrial centers is such that it has drawn the attention of scientific and executive sources for the correct disposal or principled recycling of these materials.

This study seeks to evaluate the effect of green human resources management measures through the impact of environmental knowledge upon environmental performance using evidence from small and mediumsized companies operating in the Iranian oil and gas industry.

\section{Theoretical Framework and Hypotheses}

\section{The green resources management measures and environmental performance}

Green management addresses preservation and the optimal use of scarce natural resources [Goswami, Ranjan, 2015; Renwick et al., 2016; Yu et al., 2020]. It is directly responsible for creating a work environment that understands green practices, performs them, honors them, and also protects green goals in the human resources process, including recruitment, training, compensation for services, and the development and promotion of human capital [Mathapati, 2013]. Saeed et al. examined the effect of green human management measures on employees' environmental behaviors and introduced green human resources management measures affecting such environmental behavior as employment and green choice, green education and development, green performance appraisal, green reward and compensation, and green empowerment [Saeed et al., 2018]. By selecting appropriate programs concerning the training of the organization's employees, the managers of human resources can promote the employees' awareness of environmental issues and this awareness can improve the performance of the organization in the area of environmental issues [Egri, Herman, 2000; Ahmad, 2015]. Thus, green HRM practices constitute a necessary change in the manufacturing industry [Yong et al., 2020]. The green training and development of employees describes the environmental management values for them and trains them in methods for reducing waste, increasing environmental awareness within the organization, and also provides the employees with an opportunity to participate in solving environmental problems [Zoogah, 2011; Paillé et al., 2014; Daily et al., 2012]. The environmentally friendly ideas of all employees, regardless of their position and place in the organization, should be welcomed in order to implement green empowerment, doing so will increase their interest in environmental issues [Ahmad, 2015] and strengthens environmentally friendly behaviors [ $\mathrm{Kim}$ et al., 2019] Accordingly, the first hypothesis of this study will be as follows:

H1: The environmental performance of small and medium-sized manufacturing companies is positively and significantly impacted by Green Human Resources Management Practices, such as: green selection and employment (H1a), green education and development (H1b), green empowerment of employees (H1c), green payment and reward (H1d), and green management and performance appraisal (H1e).

\section{The impact of the mediation role played by employees' environmental knowledge}

Knowledge management involves the process of optimally combining knowledge and information at an organization and creating a proper environment for production [Hajimohammadi et al., 2019]. Cheng and Wu [Cheng, Wu, 2015] found that if employees have more knowledge about environmental issues and solutions, they can react better regarding said issues. Hence, one can say that environmental knowledge can play a mediating role in the relationship between green human resources management measures and environmental performance. Accordingly, the second hypothesis of this study is as follows:

$\mathrm{H} 2$ : Green human resource management practices through employees' environmental knowledge have a positive and significant impact upon the environmental performance of small and medium companies in such 
dimensions as green selection and employment (H2a), green education and development (H2b), green empowerment of employees $(\mathrm{H} 2 \mathrm{c})$, green payment and reward $(\mathrm{H} 2 \mathrm{~d})$, and green management and performance appraisal (H2e).

According to the research goal and hypotheses, the conceptual model of this study is shown in Figure 1.

\section{Methodology}

\section{Data collection}

We used a questionnaire in this study to collect the research data. All the questionnaire questions were assessed based on a five-point Likert scale. The values of this scale were defined from 1 (very weak) to 5 (very strong). We adapted our questionnaire from the questions used in previous studies [Saeed et al., 2018; Nejati et al., 2017; Paillé et al., 2014] to measure exogenous variables. We used the Cronbach's alpha test to measure the reliability of the variables (Table 1). According to the criterion value $(0.7)$, one can say that the reliability of exogenous external variables of the research is confirmed. The questionnaire questions are provided in Table 2.

The statistical population of this study consisted of small and medium-sized companies manufacturing equipment for Iran's oil and gas industries. The number of small and medium companies operating in this industry in the survey was estimated at 84 companies. We randomly selected 30 manufacturing companies as statistical sample members. In the next step, using the databases of the selected companies, we identified and selected the respondents for the questionnaires by using the judgmental method and according to the opinions of senior human resource managers, accounting for 386 subjects. The selection criteria for these individuals were chosen based on the opinions of the companies' human resources managers, which included having necessary knowledge and experience related to the human resources management measures, green human resource management, green management, environmental knowledge management, and environmental performance. After identifying these individu-

\section{Table 1. Cronbach's Alpha Values} for the Studied Variables

\begin{tabular}{|l|l|}
\hline \multicolumn{1}{|c|}{ Variable } & Cronbach's Alpha \\
\hline \multicolumn{2}{|c|}{ Exogenous variables (Green HRM dimensions) } \\
\hline green selection and employment & 0.81 \\
\hline green training and development & 0.86 \\
\hline green empowerment & 0.83 \\
\hline green payment and reward & 0.92 \\
\hline green performance management & 0.88 \\
\hline \multicolumn{2}{|c|}{ Mediating and endogenous variables } \\
\hline environmental performance & 0.85 \\
\hline environmental knowledge & 0.94 \\
\hline Source: compiled by the authors. & \\
\hline
\end{tabular}

\section{Figure 1. The Research Conceptual Model}

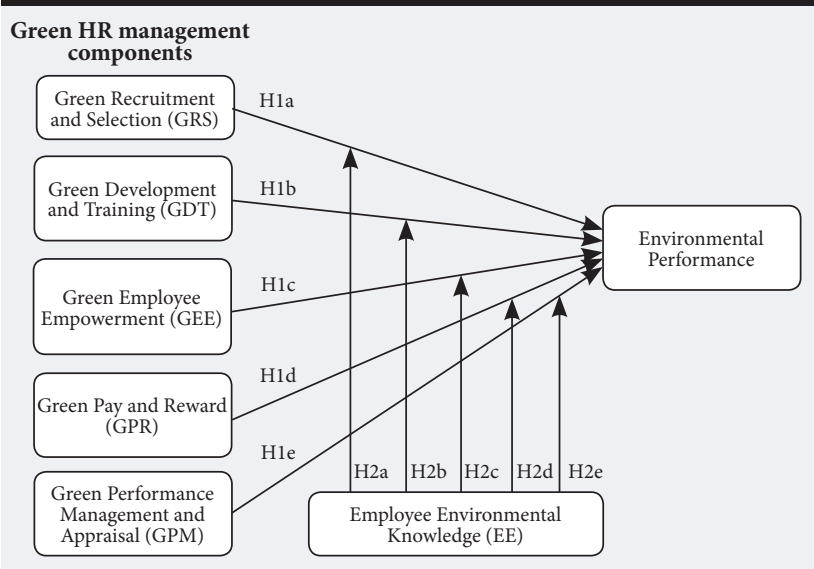

Source: compiled by the authors.

als, the questionnaires were distributed electronically among them. Three weeks after the distribution, 318 completed questionnaires were collected. It should be noted that the return rate of the completed questionnaire was estimated to be 0.82 (more than $80 \%$ ), which is an acceptable rate. In addition to the questions related to the exogenous, endogenous, and mediating variables of the research, we had also included some questions about the demographic characteristics of the respondents in the submitted questionnaires. These questions covered information on the gender, level of education, and work experience of people in the studied fields (Table 3 ).

We used the partial least squares structural equation modeling (PLS-SEM) method in this study for the analysis of the data, fitting the conceptual model of the research, and testing the hypotheses. The PLS modeling is widely used in a variety of fields, including management sciences [Wen, 2010]. Lisrel's approach focuses on maximizing the covariance and the PLS modeling focuses on variance maximization. PLS is a variance-based approach, which needs fewer conditions compared to similar structural equation techniques such as Lisrel and Amos [Liljander et al., 2009]. For example, unlike Lisrel, the PLS path modeling is more suitable for actual applications. This approach will be more desirable especially when the models are more complex [Wen, 2010]. In cases where the study aims to analyze causal relationships and prediction, the PLS path modeling method is preferred to covariance-based techniques such as Lisrel [Hair et al., 2014]. The PLS modeling is performed in three steps [Hulland, 1999]:

- the measurement model is examined through validation and reliability analyses and confirmatory factor loads analysis.

- the structural model is evaluated by estimating the path between the variables and determining the fit indices of the model. 
- the fit of the general model is validated through the GOF criterion.

\section{Evaluation of the measurement model}

In this process, the composite reliability (CR) tests and average variance extracted (AVE) are conducted and examined to obtain convergent validity and the correlation rate. A reliability above 0.7 associated with an average variance of at least 0.5 are the two conditions required for the convergent validity and correlation of a construct [Ching Lin, Chih Huang, 2009]. Factor loads greater than 0.5 also indicate good reliability for the studied constructs [Fornell, Larcker, 1981]. The Cronbach's alpha shows the level of reliability (reliability of internal consistency) of the construct. Values higher than 0.7 are considered desirable for the Cronbach's alpha, while values lower than 0.6 are considered undesirable. The divergent validity is also measured by the interaction factor loads method and the
Fornell-Larcker method. The first method includes examining the interaction factor loads in which the correlation of the indices of a construct is compared with that structure and the correlation of that index with other constructs. If the correlation of the indices of a construct with the construct other than itself is greater, the divergent validity is questioned [Ringle, Sarstedt, 2011]. The second method is the one presented by [Fornell, Larcker, 1981]. According to this method, the divergent validity is confirmed if the squared average variance extracted of each construct would be more than the correlation between the constructs.

\section{Structural model evaluation}

The path coefficients are the most basic criteria to measure the relationship between constructs in the model. In the case of path coefficients, the coefficient sign of the significance level should be considered. The paths in which the coefficients signs are opposite to the di-

Table 2. Questionnaire on Green Human Resource Management Practices

\begin{tabular}{|c|c|}
\hline Item & Questionnaire Statements \\
\hline $\begin{array}{l}\text { Green Recruitment and } \\
\text { Selection (GRS) }\end{array}$ & $\begin{array}{l}\text { - Recruitment messages include environmental behavior/commitment criteria on environmental } \\
\text { management aspects of the organizations. } \\
\text { My organization indicates or makes transparent its environmental performance (past and current) in } \\
\text { recruitment messages. } \\
\text { - My organization includes environmental criteria in the recruitment messages. } \\
\text { My organization expresses its preference for recruiting candidates who have competency and } \\
\text { attitudes predisposed toward participating in corporate environmental management initiatives in the } \\
\text { recruitment message. }\end{array}$ \\
\hline $\begin{array}{l}\text { Green Development and } \\
\text { Training (GDT) }\end{array}$ & $\begin{array}{l}\text { - Providing environmental training to the organizational members (employees and managers) to develop } \\
\text { the required skills and knowledge. } \\
\text { - Providing training to learn or adapt environmentally friendly best practices (e.g., reducing long- } \\
\text { distance business travel and recycling). } \\
\text { - Providing environmental awareness training among the workforce. } \\
\text { - Providing environmental education to the workforce. } \\
\text { - } \quad \text { Condung training to the staff to produce a green analysis of workspace. }\end{array}$ \\
\hline $\begin{array}{l}\text { Green Employee } \\
\text { Empowerment (GEE) }\end{array}$ & $\begin{array}{l}\text { Introducing green whistle-blowing and help-lines. } \\
\text { - Providing opportunities for the employee to get involved and participate in green suggestion schemes } \\
\text { and joint consultations for environmental issue problem solving. } \\
\text { Offering workshops or forums for staff to improve environmental behavior and exchange their tacit } \\
\text { knowledge. }\end{array}$ \\
\hline $\begin{array}{l}\text { Green Pay and Reward } \\
\text { (GPR) }\end{array}$ & $\begin{array}{l}\text { - The company offers nonmonetary and monetary rewards based on environmental achievements } \\
\text { (sabbatical, leave, gifts, bonuses, cash, premiums, promotion). } \\
\text { - I suggest new practices that could improve the environmental performance of my organization. } \\
\text { - At work, I question practices that are likely to hurt the environment. } \\
\text { In my work, I weigh the consequences of my actions before doing something that could affect the } \\
\text { environment. }\end{array}$ \\
\hline $\begin{array}{l}\text { Green Performance } \\
\text { Management and } \\
\text { Appraisal (GPM) }\end{array}$ & $\begin{array}{l}\text { Environmental behavior/targets and contributions to environmental management are assessed and } \\
\text { included in performance indicators/appraisal and recorded. } \\
\text { This organization provides regular feedback to the employees or teams to achieve environmental goals } \\
\text { or improve their environmental performance. } \\
\text { This organization establishes environmental management information system and environmental } \\
\text { audits. } \\
\text { This organization incorporates corporate environmental management objectives and targets with the } \\
\text { performance evaluation system. }\end{array}$ \\
\hline $\begin{array}{l}\text { Employee Environmental } \\
\text { Knowledge (EEK) }\end{array}$ & $\begin{array}{l}\text { I know about the problem of environmental pollution caused by chemicals. } \\
\text { - I have good knowledge about the environmental issues. } \\
\text { I am aware of how to protect the environment from pollution. } \\
\text { I am aware of climate change. } \\
\text { I know what clean energy is and how to promote it. } \\
\text { - I ame knowledge of landfill waste and its hazards. } \\
\text { I know about land degradation and ways to stop it. }\end{array}$ \\
\hline $\begin{array}{l}\text { Environmental } \\
\text { Performance (ENP) }\end{array}$ & $\begin{array}{l}\text { - Our firm reduced waste and emissions from its operations. } \\
\text { - Our firm reduced the environmental impacts of its products/services. } \\
\text { - Our firm reduced its environmental impact by establishing partnerships. } \\
\text { - Our firm reduced the risk of environmental accidents, spills, and releases. }\end{array}$ \\
\hline
\end{tabular}


Table 3. Demographic Characteristics of the Respondents

\begin{tabular}{|c|c|c|}
\hline Item & $\begin{array}{l}\text { Number of } \\
\text { respondents }\end{array}$ & Share (\%) \\
\hline \multicolumn{3}{|c|}{ Gender } \\
\hline Male & 255 & 80 \\
\hline Female & 63 & 20 \\
\hline \multicolumn{3}{|c|}{ Education level } \\
\hline Bachelor & 98 & 31 \\
\hline $\mathrm{PhD}$ & 31 & 10 \\
\hline \multicolumn{3}{|c|}{$\begin{array}{c}\text { Work experience in human resources management, safety } \\
\text { knowledge, and operations }\end{array}$} \\
\hline Under 5 years & 67 & 21 \\
\hline $5-10$ years & 86 & 27 \\
\hline $10-15$ years & 93 & 29 \\
\hline Over 15 years & 73 & 23 \\
\hline
\end{tabular}

rection claimed in the hypothesis will lead to the nonconfirmation of the hypothesis. Some researchers, including [Cohen, 1988], believe that the path coefficient greater than 0.1 indicates a certain amount of impact on the model, and some others, including [Chin, 1998] suggest that the value of 0.2 is the basis for showing the accuracy of the relationship between the constructs, and thus, confirming the research hypotheses at a confidence level of 95\% [Hair et al., 2010]. The t-value also indicates the accuracy rate of the relationship and is used to test the hypotheses in the PLS-SEM algorithm.

\section{Fitting the general model}

According to the structural equation modeling algorithm, the goodness of fit is used to examine the fit of the general model, which controls both measurement and structural parts. This criterion was introduced by [Tenenhaus et al., 2004] and is calculated according to the following relationship:

$\mathrm{GOF}=\sqrt{(\text { average }(\text { Communality) } \times \text { averageR2 })}$

The criterion is defined by three values of $0.01,0.25$, and 0.36 as weak, moderate, and strong values [Wetzels et al., 2009].

\section{Results}

Based on the PLS-SEM algorithm, we evaluated the measurement models at the first stage. The results of the evaluation of reliability criteria (Cronbach's alpha and composite reliability), convergent validity, and the results of factor loads measurement of the research variables given in Table 4 suggest that the values obtained for factor loads are higher than 0.5, those for the Cronbach's alpha are higher than 0.7 , and the composite reliability values are higher than the specified criterion, i.e., 0.7. Also, the result obtained from the convergent validity criterion shows that the convergent validity values of all research constructs are higher than the standard value of 0.5. The Fornell and Larcker
Table 4. The Results of the Evaluation of Factors Loads,

\begin{tabular}{|c|c|c|}
\hline Construct & Item & Factor loads \\
\hline \multirow[t]{4}{*}{ Green selection and hiring } & GRS1 & 0.709 \\
\hline & GRS2 & 0.502 \\
\hline & GRS3 & 0.709 \\
\hline & GRS4 & 0.597 \\
\hline \multirow{5}{*}{$\begin{array}{l}\text { Green training and } \\
\text { development }\end{array}$} & GDT1 & 0.624 \\
\hline & GDT2 & 0.647 \\
\hline & GDT3 & 0.640 \\
\hline & GDT4 & 0.693 \\
\hline & GDT5 & 0.834 \\
\hline \multirow[t]{5}{*}{ Green empowerment of staff } & GEE1 & 0.625 \\
\hline & GEE2 & 0.744 \\
\hline & GEE3 & 0.742 \\
\hline & GEE4 & 0.721 \\
\hline & GEE5 & 0.580 \\
\hline \multirow[t]{4}{*}{ Green payment and reward } & GPR1 & 0.631 \\
\hline & GPR2 & 0.831 \\
\hline & GPR3 & 0.700 \\
\hline & GPR4 & 0.451 \\
\hline \multirow{4}{*}{$\begin{array}{l}\text { Green management and } \\
\text { performance appraisal }\end{array}$} & GPM1 & 0.711 \\
\hline & GPM2 & 0.634 \\
\hline & GPM3 & 0.803 \\
\hline & GPM4 & 0.631 \\
\hline \multirow{9}{*}{$\begin{array}{l}\text { Employees' environmental } \\
\text { knowledge }\end{array}$} & EEK1 & 0.738 \\
\hline & EEK2 & 0.599 \\
\hline & EEK3 & 0.558 \\
\hline & EEK4 & 0.627 \\
\hline & EEK5 & 0.774 \\
\hline & EEK6 & 0.545 \\
\hline & EEK7 & 0.599 \\
\hline & EEK8 & 0.680 \\
\hline & EEK9 & 0.723 \\
\hline \multirow[t]{5}{*}{ Environmental performance } & ENP1 & 0.668 \\
\hline & ENP2 & 0.652 \\
\hline & ENP3 & 0.752 \\
\hline & ENP4 & 0.778 \\
\hline & ENP5 & 0.717 \\
\hline
\end{tabular}

method [Fornell, Larcker, 1981] was used to measure the divergent validity of the research constructs.

The results of Table 5 reveal that given that the obtained squared average variance extracted from each structure is higher than the correlation between the constructs, the divergent validity of the research constructs is confirmed. These results indicate a good internal consistency for the measurement model and report the fit of the model. As a result, the measurement model is confirmed.

After confirming the measurement model, the structural model was evaluated according to the PLS-SEM algorithm using the BOOTSTRAPPING command in the PLS software. In this command, a large number of sub-samples are extracted by the substitution method. Substitution means that whenever an observation is randomly extracted from the sampling population, before extracting the next observation, it goes back to the sampling population. That is, the population from which the observations are derived always contains similar elements. Therefore, an observation can be selected more than once or not at all in all the subsamples. The number of bootstrapping samples should 


\section{Table 5. The Results of the Evaluation of} Cronbach's Alpha, CR, and AVE

\begin{tabular}{|l|r|r|r|}
\hline \multicolumn{1}{|c|}{ Construct } & $\begin{array}{c}\text { Cronbach's } \\
\text { alpha }\end{array}$ & $\begin{array}{c}\text { Composite } \\
\text { reliability }\end{array}$ & $\begin{array}{c}\text { Convergent } \\
\text { validity }\end{array}$ \\
\hline $\begin{array}{l}\text { Green selection and } \\
\text { hiring }\end{array}$ & 0.728 & 0.726 & 0.503 \\
\hline $\begin{array}{l}\text { Green training and } \\
\text { development }\end{array}$ & 0.824 & 0.819 & 0.579 \\
\hline $\begin{array}{l}\text { Green } \\
\text { empowerment of } \\
\text { staff }\end{array}$ & 0.812 & 0.814 & 0.670 \\
\hline $\begin{array}{l}\text { Green payment and } \\
\text { reward }\end{array}$ & 0.749 & 0.755 & 0.545 \\
\hline $\begin{array}{l}\text { Green management } \\
\text { and performance } \\
\text { appraisal }\end{array}$ & 0.792 & 0.790 & 0.587 \\
\hline $\begin{array}{l}\text { Employees' } \\
\text { environmental } \\
\text { knowledge }\end{array}$ & 0.868 & 0.869 & 0.627 \\
\hline $\begin{array}{l}\text { Environmental } \\
\text { performance }\end{array}$ & 0.837 & 0.839 & 0.511 \\
\hline $\begin{array}{l}\mid l \\
\text { Source: compiled by the authors. }\end{array}$ & & \\
\hline
\end{tabular}

be high but it should be at least equal to the number of valid observations in the total data.

In this study, 5,000 bootstrapping samples were considered to calculate the significance level of the path coefficients. The results of this command are reported in Table 6. In the structural equations modeling method, after fitting the measurement models, the fitting of the structural model of the research is investigated. In analyzing the structural model, the relationships between latent variables (constructs) with each other are analyzed and the criteria of significance coefficients tvalue and the coefficient of determination or the same, $\mathrm{R}^{2}$, are used to fit the model.

The significance $t$-values are used to evaluate the fitting of the research structural model by several criteria that the first and most basic criteria are significance coefficients $t$ or the same $t$-values. The values of $t$ greater than 1.96 indicate the accuracy of relationships between the constructs, and as a result, the research hypotheses are confirmed at a 95\% confidence level. According to the results, all the numbers on the paths are higher than 1.96. This indicates that the paths are significant, the structural model is fit, and the research hypotheses are validated. These results are reported in Table 4.
The second criterion necessary for measuring the structural model fit is to determine the coefficients of determination, or the same $\mathrm{R}^{2}$ related to the endogenous latent variables (dependent variable) of the model. This criterion is used to connect the measurement and structural components of the structural equations modeling and represents the effect of an exogenous (independent) variable on an endogenous (dependent) variable. It should be noted that the $\mathrm{R}^{2}$ values of the model are calculated only for the endogenous constructs of the model and the value of this criterion is zero for the exogenous constructs of the model. There are three values of $0.19,0.33$, and 0.67 introduced as weak, moderate, and strong criteria of $\mathrm{R}^{2}$ criterion [Chin, 1998]. Given that the value of $\mathrm{R}^{2}$ for the environmental performance variable was calculated to be 0.444 , considering the three values of the criterion, the suitability of the structural model fit is confirmed.

The results of testing the first hypothesis showed that all five measures of green human resources management have a positive and significant impact upon the environmental performance of the studied companies. As a result, the first hypothesis of the study was confirmed.

The result of testing the second hypothesis of the research, which sought to evaluate the effect of the mediating role of the employees' environmental knowledge upon the relationship between green human resources management measures and environmental performance of the studied companies, revealed that the mediating role of environmental knowledge in the relationship between the four measures, namely, the green selection and employment, green training and development, green empowerment of employees, and the green management and performance appraisal respectively with path coefficients of $0.485,0.759,0.512$, and 0.380 are confirmed. In the case of the green payment and reward measure, given the value of the path coefficient of 0.105 and the $t$-value of 1.267 , which is less than the criterion value of 1.96 , this component was not confirmed. However, since four of the five sub-hypotheses related to the mediating role of environmental knowledge were confirmed, one can say that environmental knowledge plays a mediating role in the relationship between green human resources

\begin{tabular}{|c|c|c|c|c|c|c|c|}
\hline Construct & 1 & 2 & 3 & 4 & 5 & 6 & 7 \\
\hline Green selection and hiring & 0.709 & & & & & & \\
\hline Green training and development & 0.702 & 0.760 & & & & & \\
\hline Green empowerment of staff & 0.633 & 0.745 & 0.818 & & & & \\
\hline Green payment and reward & 0.659 & 0.750 & 0.810 & 0.738 & & & \\
\hline Green management and performance appraisal & 0.694 & 0.753 & 0.815 & 0.655 & 0.766 & & \\
\hline Employees' environmental knowledge & 0.643 & 0.667 & 0.795 & 0.671 & 0.668 & 0.791 & \\
\hline Environmental performance & 0.630 & 0.618 & 0.723 & 0.621 & 0.563 & 0.667 & 0.714 \\
\hline
\end{tabular}


management measures and environmental performance. Thus, the green human resources management measures have a positive and significant impact upon the environmental performance of small and mediumsized manufacturing companies operating in the oil and gas industry through the employees' environmental knowledge.

After evaluating the structural model, the general model was fitted using the GOF criterion. We used the mean of $\mathrm{R}^{2}$ values equal to 0.444 and the average common values obtained as 0.341 , in calculating the GOF criterion.

$\mathrm{GOF}==0.389$

As can be seen, the value of the GOF criterion is equal to 0.389 . This value, according to the three criterion values of $0.01,0.25$, and 0.36 as weak, moderate, and strong values for GOF, indicates a strong overall fit of the model.

\section{Discussion and Conclusion}

In this study, we examined the effect of green human resources management measures on environmental performance according to the mediating role of the employees' environmental knowledge of small and medium-sized manufacturing companies active in the Iranian oil and gas industry. As revealed by the results, one can say that the studied companies can improve their environmental performance by implementing green human resources management measures as well as promoting environmental knowledge among their employees. Table 7 summarizes the results of testing the main hypotheses and sub-hypotheses related to green HRM practices with the relevant recommendations for businesses.

The results of testing the five sub-hypotheses of the second hypothesis ( $\mathrm{H} 2 \mathrm{a}, \mathrm{H} 2 \mathrm{~b}, \mathrm{H} 2 \mathrm{c}, \mathrm{H} 2 \mathrm{~d}, \mathrm{H} 2 \mathrm{e})$ revealed that environmental knowledge plays a mediating role in the relationships between the measures of green selection and employment, green training and develop- ment, green empowerment of employees, and green management and performance appraisal and that these actions of green human resources management have a positive and significant impact upon the green environmental performance. Green training and development especially plays a crucial role in this regard. According to the results, it can be concluded that the role of human resource management can be considered successful by turning ordinary employees into green employees and refers to policies, methods, and systems that transform the employees of a green organization for the benefit of the individual, society, natural environment, and business. Human resource management measures for green staff are the prelude for building a green organization. Green human resource management refers to those human resource management actions that ultimately lead to reducing the negative effects of actions or increasing the positive environmental impacts of the organization. Accordingly, it is recommended that managers of manufacturing companies pay special attention to the environmental knowledge of employees to achieve green environmental performance and take measures such as strengthening environmental knowledge of employees through holding continuous and purposeful training courses, choosing and hiring employees with a high level of environmental knowledge, and defining the employees' performance appraisal criteria based on their level of knowledge and awareness of environmental programs and provide the organization with conditions suitable for the continuous improvement of the environmental performance.

\section{The Research Limitations and Suggestions for Future Research}

The present study faces some limitations as do other research studies. Since it was an exploratory study, the research findings are limited by the sample size and the results may change if the sample size changes. Also, different views on the research subject among mem-

\section{Table 7. The Structural Model Evaluation Results and Hypotheses Testing}

\begin{tabular}{|c|c|c|c|c|c|}
\hline $\begin{array}{c}\text { Hypothesis } \\
\text { H1: Direct effect }\end{array}$ & Path coefficient & t-value & P-value & Test result \\
\hline H1a & GRS $\rightarrow$ ENP & 0.523 & 2.072 & 0.004 & supported \\
\hline H1b & GDT $\rightarrow$ ENP & 0.884 & 3.007 & 0.000 & supported \\
\hline H1c & GEE $\rightarrow$ ENP & 0.380 & 2.189 & 0.002 & supported \\
\hline H1d & GPR $\rightarrow$ ENP & 0.420 & 1.980 & 0.048 & supported \\
\hline H1e & GPM $\rightarrow$ ENP & 0.711 & 2.865 & 0.000 & supported \\
\hline Hediator effect & GRS $\rightarrow$ EEK $\rightarrow$ ENP & 0.485 & 2.333 & 0.001 & supported \\
\hline H2a & GDT $\rightarrow$ EEK $\rightarrow$ ENP & 0.759 & 3.422 & 0.000 & supported \\
\hline H2b & GEE $\rightarrow$ EEK $\rightarrow$ ENP & 0.512 & 2.451 & 0.000 & supported \\
\hline H2c & GPR $\rightarrow$ EEK $\rightarrow$ ENP & 0.105 & 1.267 & 0.072 & not supported \\
\hline H2d & GPM $\rightarrow$ EEK $\rightarrow$ ENP & 0.380 & 2.147 & 0.008 & supported \\
\hline H2e & & & \\
\hline
\end{tabular}


Table 8. Recommendations on Green HRM Practices that Enable the Improvement of Firms' Environmental Performance

\begin{tabular}{|c|c|c|c|c|}
\hline Hypothesis & \begin{tabular}{|c|} 
Linking path \\
between \\
variables \\
\end{tabular} & $\begin{array}{c}\text { Path } \\
\text { coefficient }\end{array}$ & $\begin{array}{c}\text { Previous studies that } \\
\text { confirm hypothesis testing }\end{array}$ & Recommendations for businesses \\
\hline H1a & GRS $\rightarrow$ ENP & 0.523 & $\begin{array}{l}\text { [Masri, Jaroon, 2017; Roscoe } \\
\text { et al., 2018] }\end{array}$ & $\begin{array}{l}\text { Choosing employees interested in environmental activities, } \\
\text { considering the environmental background of individuals } \\
\text { in the recruitment process as well as focusing on the } \\
\text { implementation of environmental principles by employees } \\
\text { in the employment interview questions }\end{array}$ \\
\hline $\mathrm{H} 1 \mathrm{~b}$ & GDT $\rightarrow$ ENP & 0.884 & $\begin{array}{l}\text { [Paillé et al., 2014; } \\
\text { Bombiak, Marciniuk- } \\
\text { Kluska, 2018; Rawashdeh, } \\
\text { 2018] }\end{array}$ & $\begin{array}{l}\text { Facilitating the employees' participation by providing } \\
\text { training and preparing programs to improve the } \\
\text { employees' skills and knowledge, promoting the employee's } \\
\text { environmental behavior by holding training courses related } \\
\text { to environmental issues in the workplace, and thereby, } \\
\text { developing the employees' environmental knowledge }\end{array}$ \\
\hline H1c & $\mathrm{GEE} \rightarrow \mathrm{ENP}$ & 0.380 & $\begin{array}{l}\text { [Rawashdeh, 2018; Mishra, } \\
\text { 2017] }\end{array}$ & $\begin{array}{l}\text { Gathering the opinions and suggestions from the } \\
\text { employees concerning environmental issues by } \\
\text { formulating the necessary processes and encouraging } \\
\text { employees further participation }\end{array}$ \\
\hline H1d & GPR $\rightarrow$ ENP & 0.420 & $\begin{array}{l}\text { [Saeed et al., 2018; Paillé et } \\
\text { al., 2014; Ahmad, 2015] }\end{array}$ & $\begin{array}{l}\text { Creating the necessary motivation for environmental } \\
\text { activities among employees by operationalizing measures } \\
\text { such as defining rewards and appropriate payments for } \\
\text { employees with proper performance in environmental } \\
\text { activities, rewarding employees who have achieved } \\
\text { environmental goals or exceeded the defined goals }\end{array}$ \\
\hline H1e & $\mathrm{GPM} \rightarrow \mathrm{ENP}$ & 0.711 & $\begin{array}{l}\text { [Paillé et al., 2014; Mishra, } \\
\text { 2017; Rawashdeh, 2018; } \\
\text { Saeed et al., 2018] }\end{array}$ & $\begin{array}{l}\text { Setting specific environmental goals for employees } \\
\text { and defining performance appraisal criteria with an } \\
\text { environmental approach so that achieving environmental } \\
\text { goals by employees would be considered an important } \\
\text { criterion in evaluating their organizational performance }\end{array}$ \\
\hline
\end{tabular}

bers of the statistical population can affect the results. The studied population in this research study included small and medium-sized manufacturing companies active in Iran's oil and gas industry. Accordingly, the results obtained are specific to these companies and cannot be generalized to apply to all organizations and companies. It is recommended that researchers conduct future research on this topic at other organizations as well as manufacturing and service companies in the oil and gas industry worldwide and other industries. Given that five important measures of green human resources management were used as effective variables on the environmental performance in this study due to their frequent use in previous studies related to the manufacturing industry, it is suggested that researchers examine the impact of other green human resources management measures, including green human resources planning and green safety management and discipline concerning environmental performance in future research. The employees' environmental knowledge variable was used as the mediating variable in this study. Based on this fact, it is suggested that researchers use variables such as green commitment and green lifestyle as mediating variables in future research. Since both objective and subjective knowledge can be examined to measure the environmental knowledge of employees, due to the limitation in data collection, this study focused only on subjective knowledge. Thus, it is recommended that a study be conducted in the context of objective and subjective knowledge simultaneously to measure environmental knowledge in the future.

The authors would like to thank the management of Petro Savin Sanat Eng. Co., who were very helpful in conducting this study. The company's executives helped the authors collect data related to the industry in question.

\section{References}

Ahmad S. (2015) Green human resource management: Policies and practices. Cogent Business \& Management, (2)1, 1-13. https://doi.org/1 $0.1080 / 23311975.2015 .1030817$

Angelovska J., Sotiroska S., Angelovska N. (2012) The Impact of Environmental Concern and Awareness on Consumer Behavior. Journal of International Environmental Application \& Science, 7(2), 406-416.

Bombiak E., Marciniuk-Kluska A. (2018) Green Human Resource Management as a Tool for the Sustainable Development of Enterprises: Polish Young Company Experience. Sustainability, 10(6), 1739. https://doi.org/10.3390/su10061739

Cheng T.M., Wu H.C. (2015) How do environmental knowledge, environmental sensitivity, and place attachment affect environmentally responsible behavior? An integrated approach for sustainable island tourism. Journal of Sustainable Tourism, 23(4), 557-576. https:// doi.org/10.1080/09669582.2014.965177

Chin W.W. (1998) Issues and opinion on structural equation modeling. MIS Quarterly, 22(1), 7-16.

Ching Lin T., Chih Huang C. (2009) Understanding social loafing in knowledge contribution from the perspectives of justice and trust. Expert Systems with Applications, 36, 6156-6163. https://doi.org/10.1016/j.eswa.2008.07.014 
Clair J., Milliman J. (2017) Best environmental HRM practices in the US. In: Greening People (ed. W. Wehrmeyer), New York: Routledge, 49-73. https://doi.org/10.4324/9781351283045

Cohen J. (1988) Statistical Power Analysis for the Behavioral Sciences, New Jersey: Hillsdale, Lawrence Erlbaum Associates.

Daily B.F., Bishop J.W., Massoud J.A. (2012) The role of training and empowerment in environmental performance: A study of the Mexican maquiladora industry. International Journal of Operations \& Production Management, 32(5), 631-647. https://doi. org/10.1108/01443571211226524

Egri C.P., Herman S. (2000) Leadership in the North American environmental sector: Values, leadership styles and contexts of environmental leaders and their organizations. Academy of Management Journal, 43(4), 571-604. https://doi.org/10.5465/1556356

Fornell C., Larcker D. (1981) Structural equation models with unobservable variables and measurement error. Journal of Marketing Research, 18(1), 39-50. https://doi.org/10.1177\%2F002224378101800313

González J., González O. (2006) A review of determinant factors of environmental proactivity. Business Strategy and the Environment, 15(2), 87-102. https://doi.org/10.1002/bse.450

Goswami T.G., Ranjan S.K. (2015) Green HRM: Approach to sustainability in current scenario. Journal for Studies in Management and Planning, (1)4, 250-259.

Guzman A., Heinen J.T., Sah J.P. (2020) Evaluating the Conservation Attitudes, Awareness and Knowledge of Residents towards Vieques National Wildlife Refuge, Puerto Rico. Conservation \& Society, 18(1), 13-24. DOI: 10.4103/cs.cs_19_46

Hair J.F., Black W.C., Babin B.J., Anderson R.E., Tatham R.L. (2010) Multivariate data analysis (7 ${ }^{\text {th }}$ ed.), Upper Saddle River, NJ: Prentice Hall.

Hair J.F., Hult G.T.M., Ringle C., Sarstedt M. (2014) A primer on partial least squares structural equation modeling (PLS-SEM), Thousand Oaks, CA: Sage Publications.

Hajimohammadi M., Bazrkar A., Vafaei S. (2019) Creating a Sustainable Competitive Advantage for Organizations through the Implementation of Knowledge Management with the Help of Modern Information Technology. IJERI: International Journal of Educational Research and Innovation, 12, 203-216.

Hulland J. (1999) Use of partial least squares (PLS) in strategic management research: A review of four recent studies. Strategic Management Journal, 20(2), 195-204. https://doi.org/10.1002/(SICI)1097-0266(199902)20:2<195::AID-SMJ13>3.0.CO;2-7

Jabbour C.J.C. (2013) Environmental training in organizations: From a literature review to a framework for future research. Resources, Conservation and Recycling, 74(1), 144-155. https://doi.org/10.1016/j.resconrec.2012.12.017

Jaramillo J.Á., Sossa J.W.Z., Mendoza G.L.O. (2018) Barriers to sustainability for small and medium enterprises in the framework of sustainable development - Literature review. Business Strategy and the Environment, 28(4), 512-524. https://doi.org/10.1002/bse.2261

Kim Y.J., Kim W.G., Choi H.M., Phetvaroon K. (2019) The effect of green human resource management on hotel employees' eco-friendly behavior and environmental performance. International Journal of Hospitality Management, 76, 83-93. https://doi.org/10.1016/j. ijhm.2018.04.007

Liljander V., Polsa P., van Riel A. (2009) Modelling consumer responses to an apparel store brand: Store image as a risk reducer. Journal of Retailing and Consumer Services, 16, 281-290. https://doi.org/10.1016/j.jretconser.2009.02.005

Masri H.A., Jaaron A.A. (2017) Assessing green human resources management practices in Palestinian manufacturing context: An empirical study. Journal of Cleaner Production, 143, 474-489. https://doi.org/10.1016/j.jclepro.2016.12.087

Mathapati C.M. (2013) Green HRM: A strategic facet. Tactful Management Research Journal, 2(2), 1-6.

Mishra P. (2017) Green human resource management: A framework for sustainable organizational development in an emerging economy. International Journal of Organizational Analysis, 25(5), 762-788. https://doi.org/10.1108/IJOA-11-2016-1079

Nejati M., Rabiei S., Jabbour C.J.C. (2017) Envisioning the invisible: Understanding the synergy between green human resource management and green supply chain management in manufacturing firms in Iran in light of the moderating effect of employees' resistance to change. Journal of Cleaner Production, 168, 163-172. https://doi.org/10.1016/j.jclepro.2017.08.213

Paillé P., Chen Y., Boiral O., Jin J. (2014) The impact of human resource management on environmental performance: An employee-level study. Journal of Business Ethics, 121(3), 451-466. https://doi.org/10.1007/s10551-013-1732-0

Pan S.L., Chou J., Morrison A.M., Huang W.S., Lin M.C. (2018) Will the future be greener? The environmental behavioral intentions of university tourism students. Sustainability, 10(3), 1-17. https://doi.org/10.3390/su10030634

Pham N.T., Tučková Z., Jabbour C.J.C. (2019) Greening the hospitality industry: How do green human resource management practices influence organizational citizenship behavior in hotels. Tourism Management, 72, 386-399. https://doi.org/10.1016/j. tourman.2018.12.008

Rawashdeh A. (2018) The impact of green human resource management on organizational environmental performance in Jordanian health service organizations. Management Science Letters, 8(10), 1049-1058. DOI: 10.5267/j.msl.2018.7.006

Renwick D.W.S., Jabbour C.J.C., Muller Gammanym R., Wilkinson A. (2016) Contemporary developments in Green (environmental) HRM scholarship. International Journal Human Resource Management, 27(2), 114-128. https://doi.org/10.1080/09585192.2015.1105844

Ringle C.M., Sarstedt M. (2011) Structural modeling of heterogeneous data with partial least square. In: Review of Marketing Research (ed. N.K. Malhotra), Bingley: Emerald Group Publishing Limited, vol. 7, pp. 255-296. https://doi.org/10.1108/S15486435(2010)0000007011

Roscoe S., Subramanian N., Jabbour C.J.C., Chong T. (2019) Green human resource management and the enablers of green organizational culture: Enhancing a firm's environmental performance for sustainable development. Business Strategy and the Environment, 28, 737-749. https://doi.org/10.1002/bse.2277

Saeed B.B., Afsar B., Hafeez S., Khan I., Tahir M., Afridi M.A. (2018) Promoting employee’s proenvironmental behavior through green human resource management practices. Corporate Social Responsibility Environmental Management, 26, 424-438. https://doi.org/10.1002/ bse. 2277

Tenenhaus M., Amatos S., Esposite Vinzi V. (2004) A global goodness of fit index for PLS Structural equation modeling. In: Proceeding of the XLII SIS Scientific Meeting, 1, 739-742. https://www.academia.edu/17633234/A_global_Goodness_of_Fit_index_for_PLS_structural_ equation_modelling, accessed 19.11.2020.

Wen W.S. (2010) Linking Bayesian networks and PLS path modeling for causal analysis. Expert Systems with Applications, 37, $134-139$. https://doi.org/10.1016/j.eswa.2009.05.021

Wetzels M., Odekeken-Schroder G., Van Oppen C. (2009) Using PLS path modeling for accessing hierarchical construct models: Guidelines and empirical illustrations. MIS Quarterly, 33(1), 177-195. https://doi.org/10.2307/20650284

Yong J.Y., Yusliza M.-Y., Ramayah T., Jabbour C.J.C., Sehnem S., Venkatesh M. (2020) Pathways towards sustainability in manufacturing organizations: Empirical evidence on the role of green human resource management. Business Strategy and the Environment, 29(1), 212228. https://doi.org/10.1002/bse.2359

Yu W., Chavez R., Feng M., Wong C.Y., Fynes B. (2020) Green human resource management and environmental cooperation: An ability-motivation-opportunity and contingency perspective. International Journal of Production Economics, 219, 224-235. https://doi. org/10.1016/j.ijpe.2019.06.013

Zhao H.H., Gao Q., Wu Y.P., Wang Y., Zhu X.D. (2014) What affects green consumer behavior in China? A case study from Qingdao. Journal of Cleaner Production, 63, 143-151. https://doi.org/10.1016/j.jclepro.2013.05.021

Zoogah D. (2011) The dynamics of Green HRM behaviors: A cognitive social information processing approach. Zeitschrift fur Personal Forschung, 25, 117-139. https://doi.org/10.1177\%2F239700221102500204 